\title{
Comparative performance of tractor operated boom type field sprayers on cotton crop
}

\section{BABASAHEB GHOLAP AND OMKAR SINGH KUSHWAH}

Received : 06.02.2015; Revised : 01.03.2015; Accepted : 12.03.2015

See end of the Paper for authors' affiliation

Correspondence to :

BABASAHEB GHOLAP Agricultural Energy and Power Division, Central Institute of Agricultural Engineering, BHOPAL (M.P.) INDIA
-ABSTRACT : Boom sprayers are the hydraulic equipment in which sprayers move the liquid to the individual nozzles along the boom and generally used for application of pesticides on field crops such as cotton, soybean etc. Two 12 meter tractor operated boom type field sprayers of the ASPEE make one of the existing design and other of new design (developed) having similar specifications were selected for the study. The necessary set up was built up in the laboratory and said sprayers were evaluated for their performance for the parameters such as liquid distribution, flow rate of the pump, pressure and discharge of nozzles and droplet deposition on the leaves of cotton plant. Comparative performance showed that the liquid distribution under the developed boom sprayer improved, the mean discharge and pressure of developed boom sprayer increased by 49 per cent and 184.4 per cent, respectively. The discharge and pressure of the developed boom sprayer was nearly uniform in all nozzles, droplet size (VMD), droplet density (DD) and uniformity co-efficient (UC) for the existing sprayer ranged from 130.9 to $206.39 \mu \mathrm{m}, 11$ to $27 \mathrm{drops} / \mathrm{cm}^{2}$ and 1.18 to 1.31 , whereas for developed sprayer it was ranged from 155.44 to $181.55 \mu \mathrm{m}, 17$ to 29 drops/ $\mathrm{cm}^{2}$ and 0.99 to 1.23 , respectively.

- KEY WORDS : Boom sprayer, Cotton crop, Droplet deposition, Comparative performance

- HOW TO CITE THIS PAPER : Gholap, Babasaheb and Kushwah, Omkar Singh (2015). Comparative performance of tractor operated boom type field sprayers on cotton crop. Internat. J. Agric. Engg., 8(1) : 85-91. 